\title{
Modelling Groundwater Flow and Contaminant Migration in Heterogeneous Fractured Media at a Municipal Solid Waste Landfill in Nanjing Lishui, China
}

\author{
Xiaochang Sun, ${ }^{1}$ Yin Jiang $\mathbb{D}^{2},{ }^{2}$ Yong Huang, ${ }^{2}$ Yue Su $\mathbb{D},{ }^{2}$ and Kehan Miao $\mathbb{D}^{2}$ \\ ${ }^{1}$ Jiangsu Tianyuan Group, China \\ ${ }^{2}$ School of Earth Sciences and Engineering, Hohai University, Nanjing 211100, China \\ Correspondence should be addressed to Yin Jiang; jiangyin1@hhu.edu.cn
}

Received 6 December 2021; Revised 4 February 2022; Accepted 12 February 2022; Published 27 February 2022

Academic Editor: Venkatramanan Senapathi

Copyright (c) 2022 Xiaochang Sun et al. This is an open access article distributed under the Creative Commons Attribution License, which permits unrestricted use, distribution, and reproduction in any medium, provided the original work is properly cited.

\begin{abstract}
The migration of groundwater flow and contaminants in fractured medium is complicated owing to the strong heterogeneity and anisotropy of fractured rock mass. Taking the environmental restoration and groundwater protection of the Lishui domestic waste landfill in Nanjing as the background, the groundwater environmental impact assessment and prediction are conducted for the groundwater environmental pollution that may be caused by the leakage of the landfill leachate after the closure of the domestic waste landfill. The strata of the landfill site are clay-cobble gravel, strongly and moderately weathered breccia, with obvious anisotropy and significant differences in rock mass permeability. A 3D numerical model of groundwater flow and contaminant migration in the landfill area is established by integrating the hydrogeological field tests and a conceptual model in the study area. Based on the parametric inversion method, the heterogeneous anisotropic permeability coefficient of the fractured medium is calibrated, and the temporal and spatial migration characteristics of contaminants such as ammonia nitrogen and mercury are predicted using the corrected model under the normal and failure conditions of the antiseepage curtain. The calculated results show that when the antiseepage fails, the maximum migration distances of contaminants in the horizontal direction after 100 days in the old and new landfills are $7.66 \mathrm{~m}$ and $15.64 \mathrm{~m}$, respectively, and the maximum migration distances after 20 years are $192.5 \mathrm{~m}$ and $113.89 \mathrm{~m}$, respectively. The migration direction and distances of contaminants are consistent with the hydrogeological conditions of the study area. The model calculation results provide a corresponding basis for the antiseepage control of contaminants.
\end{abstract}

\section{Introduction}

The disposal of municipal solid waste has been one of the most significant problems worldwide, especially in developing countries [1]. In both developed and developing countries, landfilling is the simplest, cheapest, and most cost-effective way of waste disposal [2,3]. Although landfills are the least popular method of municipal solid waste disposal, they are still widely used [4-11]. Hundreds of thousands of municipal solid waste landfills have been constructed around the globe [12]. However, the possibility for contamination of groundwater resources by leachate from landfills has led to potential social and environmental prob- lems [13-17]. The social and environmental impacts of municipal solid waste have attracted much attention in recent years [18].

The harmful effects of waste leachate infiltration into groundwater mean that the assessment of these impacts has attracted much research attention in recent years [19]. Due to the large increase in population and the need for safe sources of drinking water, these studies have become increasingly important [20]. Nagarajan et al. [21] investigated the impact of leachate on groundwater quality, caused by nonengineered municipal solid waste landfills. Various physicochemical parameters in leachate and groundwater samples were studied to understand the possible connection 
of groundwater contamination. The results of this study proved the existence of contaminants in groundwater and warned of dangers in its quality, especially near the landfills. El Salam and Abu Zuid [22] evaluated the environmental impacts associated with solid waste landfills by analysing leachate and groundwater quality. The results of the physicochemical analysis of leachate proved that the characteristics of leachate were highly variable. Besides, the contamination of organic matter, salts, and heavy metals was severe. Due to the variability in composition and flow rate, seasonal variations in precipitation, type, and age of the facility, landfill leachate is one of the most difficult wastewater to treat $[8,23]$. Contaminant transport in groundwater is mainly influenced by the flow direction of groundwater and hydraulic conductivity in the aquifer beneath the landfill, the amount of water entering the aquifer, and the concentration of contaminants at the source [24]. Hydraulic conductivity $(K)$ mainly affects the contaminant fate and transport [25]. Ahmed et al. [26] established a three-dimensional simulation model by combining modular finite-difference flow model and the modular three-dimensional transport model, which was applied to the leachate collection site to elucidate the fate and migration of the leachate from collection site bed into the groundwater. Results showed a good match between numerical model results and experimental measurements. Aromolaran et al. [27] explored the pollution of groundwater by leachate emanating from Aba-Eku MSW dumpsite in Ibadan, Nigeria, and found the twodimensional subsurface model revealed a leachate plume extending beyond $5 \mathrm{~m}$ and the MSW leachate is heterogeneous. Fandino et al. [28] investigated the dispersion of leachate from urban solid waste through saturated soil using the codes MODFLOW and MT3DMS. It was concluded that the landfill had the potential to pollute the surrounding soil and groundwater. In last year, the pollutant concentration model, leakage rate model, and the solute transport model were coupled to evaluate the effect of municipal solid waste landfill on groundwater quality by Zhang et al. [29].

These studies are generally sampled for laboratory analysis or use simulation software based on finite difference method, while simulation software based on finite element method is more precise with regard to the geometric structure of the study model and actual study area. Besides, combining with the hydrogeological field tests and conceptual model in the study area, the numerical model of groundwater flow and contaminant migration in the landfill area is found to be more accurate.

The purpose of this study is to predict the migration of contaminants in waste landfill leachate through numerical simulation evaluation based on the actual situation of Lishui municipal solid waste landfill in Nanjing, China. The hydrogeological parameters were calibrated by means of hydrogeological field tests and parameter inversions. The effects of initial concentration of contaminants in leachate, the leachate water head, and diffusion were considered. The established three-dimensional groundwater flow and contaminant migration model highlight the heterogeneity and anisotropy of the fractured medium. The results can provide corresponding technical support for the design of landfill closure and have reference significance for the construction of similar projects.

\section{Study Area}

2.1. Location. The project is in Lishui District and the central southern part of Nanjing. It is an important national film and television base, an agricultural science and technology base, a significant transportation hub and logistics centre in East China, a manufacturing base and modern industrial cluster in the Yangtze River Delta region, and one of the four vice-cities of Nanjing. Lishui District is adjacent to Liyang City in the east, Gaochun District in the south, Bowang District in Ma'an City, Anhui Province in the west, Jiangning District in the northwest, and Jurong City in the northeast. It is located at $31^{\circ} 23^{\prime}-31^{\circ} 48^{\prime} \mathrm{N}, 118^{\circ} 51^{\prime}-119^{\circ} 14^{\prime} \mathrm{E}$, with an area of $1067 \mathrm{~km}^{2}$ (Figure 1). The study area belongs to the lower Yangtze River depression belt of the Yangtze River's ancient landscape in terms of the geological structure. As a result of lake sedimentation and lithological influence, the area has formed a topographic landscape with exfoliated low hills as the main feature and river valley plains and lakeside estuarine delta plains as the second.

The study area has a north subtropical monsoon climate with four distinct seasons, hot and humid in summer and cold and dry in winter. The annual average temperature is $16.4^{\circ} \mathrm{C}$. The annual average relative humidity is $76 \%$. The annual average precipitation is $1204.3 \mathrm{~mm}$ with the rainfall infiltration coefficient of $0.05-0.2$. The annual average precipitation time is 123 days, and the annual average sunshine is 1980 hours. The rainy season is from mid to late-June to early-July each year. The average annual evaporation is $1038 \mathrm{~mm}$, and the limit depth of groundwater evaporation is about $5 \mathrm{~m}$. The annual average surface runoff is 420 million cubic meters. The study area mainly belongs to the Shijiu Lake and the Qinhuai River water systems, of which the Qinhuai River Basin is $464.82 \mathrm{~km}^{2}$, the Shijiu Lake Basin is $599.39 \mathrm{~km}^{2}$, and only $2.73 \mathrm{~km}^{2}$ in the southeast corner of the mountainous area belongs to the Taihu Lake Water System. The watershed of the two major water systems runs across the middle of the area from east to west, which divides the river flow in the area into two directions, north and south.

2.2. Project Overview. There are two municipal solid waste disposal facilities in Lishui District: Lishui District Municipal Solid Waste Simple Landfill (old waste landfill) and Lishui District Municipal Solid Waste Sanitary Landfill (new waste landfill). The old waste landfill is located $50 \mathrm{~m}$ southwest of the new waste landfill (Figure 1). Covering an area of about $54,000 \mathrm{~m}^{2}$, it was opened for use in 1993 and has been filled to an extent of about $700,000 \mathrm{~m}^{3}$ of municipal solid waste. Its storage capacity has been used up. The landfill was built without corresponding pollution prevention facilities, such as bottom-impermeability and leachate treatment facilities. The new landfill storage area opened to use in 2008, covering an area of about $28,000 \mathrm{~m}^{2}$, with about $350,000 \mathrm{~m}^{3}$ of municipal solid waste landfilled. Its storage capacity of the north side of the landfill is going to be used up soon. 

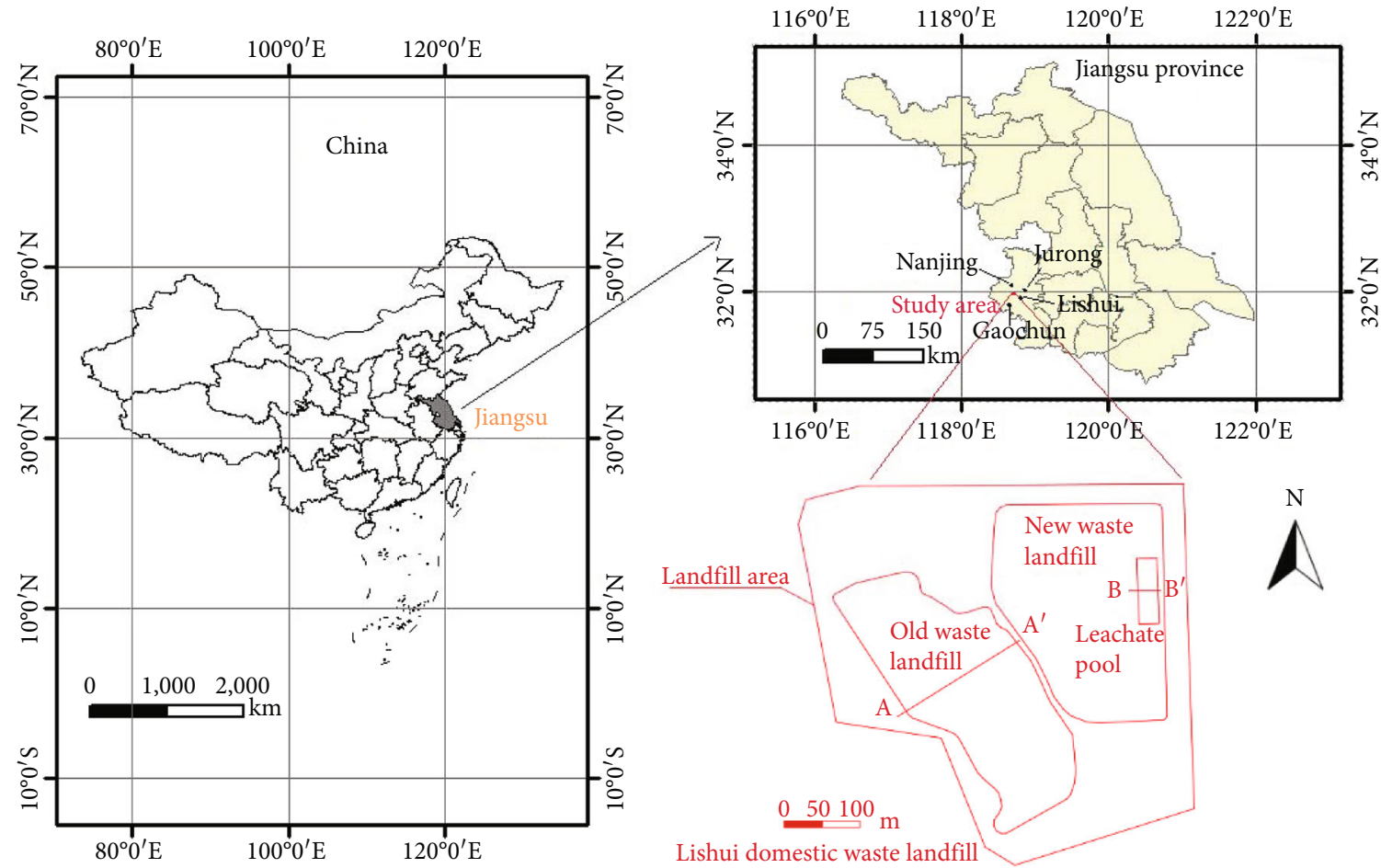

Figure 1: Location of study area.

The landfill is about to reach its final service life, and there is not much storage capacity left (in 2016). In addition, with the expansion of urban construction in Lishui City, the landfill has been gradually close to the densely populated areas of the city. To limit the uncontrolled piling of the old landfill, control the environmental pollution caused by leachate and odour, eliminate potential safety hazards, and reduce the damage to the environment, and the threat to public health is necessary to seal the old landfill and the reservoir area on the north side of the new landfill, according to the national standard and the new landfill anticipated to fill soon. The aims are thoroughly remedying the environmental pollution problems left in the use of the landfill and improving the landfill and surrounding environment. Nanjing Lishui District Urban Management Bureau intends to invest $¥ 54.758$ million to implement the closure of the Lishui landfill. The main stages of the closure project include pile trimming, closure and coverage, installation of vertical antiseepage measures, installation of a leachate collection system, landfill gas drainage works, a surface water drainage system, and greening projects.

\subsection{Geological Framework}

2.3.1. Stratigraphy and Lithology. The stratigraphy of the study area from top to bottom is described as follows:

Layer $\mathrm{I}_{1}\left(\mathrm{Q}^{\mathrm{ml}}\right)$ is the miscellaneous fill which is composed of clayey soil, broken bricks, rubble, and other construction waste, with miscellaneous colour and loose structure. Its thickness is in the range of $0.60-5.80 \mathrm{~m}$.

Layer $\mathrm{I}_{2}\left(\mathrm{Q}^{\mathrm{ml}}\right)$ is the plain fill which is mainly composed of clayey soil, occasionally broken bricks, broken stones, and plant roots, with yellowish brown to greyish brown. The age of the fill exceeds 10 years, with loose structure and poor uniformity. Its thickness is about $0.5-1.5 \mathrm{~m}$.

Layer $\left(1_{3}\left(Q^{\mathrm{ml}}\right)\right.$ is miscellaneous fill which is mainly composed of domestic garbage, locally interspersed with gravel, bricks, etc., with a grey-black colour. Its thickness is around 1.1-10.9 m.

Layer (3) $\left(\mathrm{Q}_{3}{ }^{\mathrm{al}}\right)$ is a clay with pebbles and gravels: they are brownish red. The pebbles of grain size are between 20 and $100 \mathrm{~mm}$ comprising about $10 \%-30 \%$ by mass of the total. They are mainly subrounded, irregularly arranged, and locally blocky. The mixture has a low plasticity, with locally plastic, intermediate compressibility zones. Its thickness is $3.4-16.5 \mathrm{~m}$.

Layer (4) $\left(\mathrm{J}_{3}{ }^{1}\right)$ contains strongly weathered breccia. They are brownish red, with the shape of broken blocks. The number of standard penetration test blows is greater than 50 , and it is easy to break by hammering. It is classified as a relatively soft rock. The basic quality grade of the rock is class $\mathrm{V}$, and the thickness is $0.6-1.5 \mathrm{~m}$.

Layer (4) ${ }_{2}\left(\mathrm{~J}_{3}{ }^{\mathrm{l}}\right)$ is a moderately weathered breccia. It is brownish red and slightly fissured. The coring rate is generally $60 \%-90 \%$. The rock is generally complete, and the core is short, columnar, and breakable by hammering. It is classified as a relatively soft rock. The basic quality grade of the rock is class IV, and its thickness is 5.3-24.7 m (Figure 2).

2.3.2. Groundwater Types and Hydrogeological Zoning. The whole area of Lishui lies in the Ningwu Jurassic volcanic basin, and the type of groundwater is singular. Except for a small amount of pore water of the Quaternary System covering layer on the surface, all of them are fractured water 


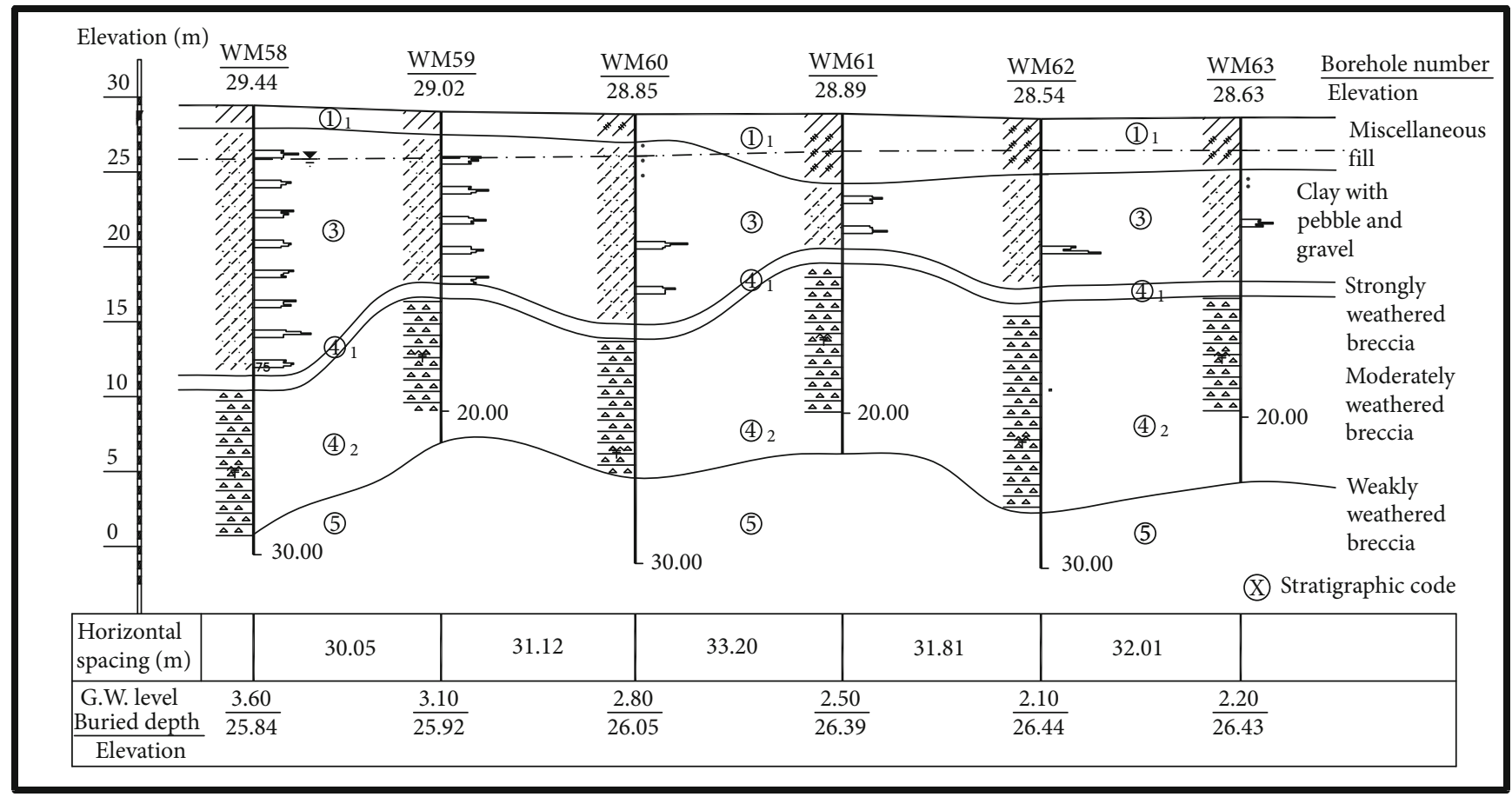

FIgURE 2: Geological cross section through the study area.

reservoirs. According to the geomorphological and hydrogeological characteristics, the Lishui area can be divided into two hydrogeological zones, the Qinhuai River floodplain zone and a hilly zone. And the hilly zone can be divided into subzones comprising exposed bedrock and Quaternary System coverage.

(1) Qinhuai River Floodplain Zone $\left(I_{5}\right)$. The zone is in the north of Lishui District, with an area of about $5 \mathrm{~km}^{2}$. There are no borehole data in the whole area. It is speculated that the sediment thickness is $20-30 \mathrm{~m}$, and the water inflow to a single well is $100-300 \mathrm{~m}^{3} / \mathrm{d}$. The deep part is Jurassic volcanic clastic rocks (Figure 3 ).

(2) Hilly Zone $\left(\mathrm{III}_{5}\right)$. The exposed bedrock subzone $\left(\mathrm{III}_{5}{ }^{1}\right)$ is the most widely distributed area in the region with a total area of $830 \mathrm{~km}^{2}$. Except where the surface layer is covered with a thin layer of cohesive soil, a large area of bedrock is exposed. The exposed bedrock in this area mainly includes the upper Jurassic $\left(\mathrm{J}_{3}{ }^{2}\right)$ volcanic rocks and volcanic clastic rocks and lower $\mathrm{J}_{3}{ }^{1}$ clastic rocks and volcanic clastic rocks. The sandstone of the Lower Middle Jurassic $\left(\mathrm{J}_{1-2}\right)$ Xiangshan Group and the sandstone of the Middle Triassic Huangmaqing Group $\left(\mathrm{T}_{2} \mathrm{~h}\right)$ are exposed in some parts of the area. There are intrusions of rough porphyry and amphibolite in Huashan in the west of the city and Wushan and Qunli in the north of the city. There are Devonian sandstones and Silurian mud shales exposed in the area from Baima Town south to Zhishan in the southeast of the city, which is the southern extension of the Maoshan Mountain Range.

The groundwater types in this area are all fractured water. The overall water volume is not large, and the flow rate is mostly less than $300 \mathrm{~m}^{3} / \mathrm{d}$. Only some well holes can

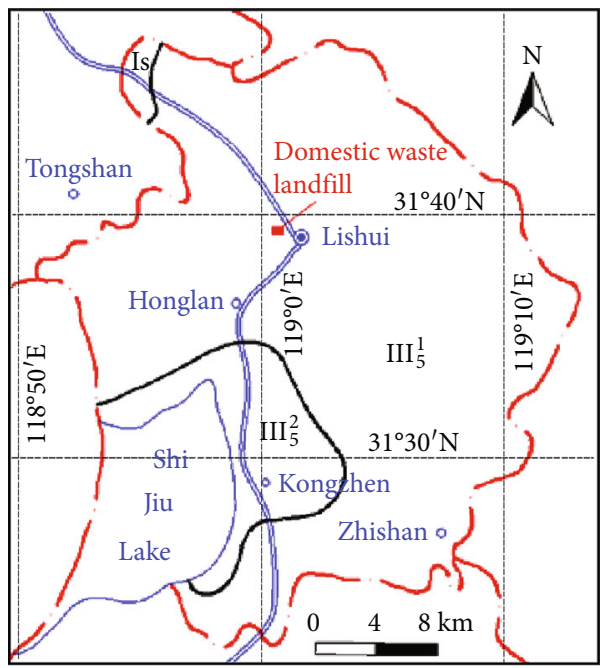

Figure 3: Hydrogeological zoning map of Lishui District.

reach about $1000 \mathrm{~m}^{3} / \mathrm{d}$. Water richness is mainly controlled by lithology and structural fractures. The area containing hard volcanic rocks and coarse sandstone is more waterrich. In the area containing soft sandstone, siltstone, and mud shale, there is less water. In addition to lithological factors, structural faults play a leading role. Near tensional and tension-torsional fault zones and at the contact area between intrusive rocks and volcanic clastic rocks and clastic rocks, the water volume is large. On the contrary, the water volume is small or even absent elsewhere. Clastic and volcanic clastic rocks are affected by intrusions, so that the surrounding rocks are thermally altered and the intrusive rocks of the 
top support extrusion, so that the fracture is enhanced, which is conducive to the enrichment of groundwater transport and the increased flow of water. For example, the deep well of Wushan Mineral Water Factory is on the fault zone and is influenced by the intrusion of Wushan sphalerite; thus, the water volume is very large, with the water level dropping some $0.98 \mathrm{~m}$ and the flow rate reaching $1680 \mathrm{~m}^{3} / \mathrm{d}$. The fracture connectivity in this area is weak, mostly in the form of belts or pipes. In the same area, there is a well with large water volume, while another nearby well yields little to no water (as at the North Industrial Factory in Lishui District City). There are two wells in the factory area about $200 \mathrm{~m}$ from each other, and their water quality and yield are very different. The maximum water volume of single well is $103 \mathrm{~m}^{3} / \mathrm{d}$ and $24 \mathrm{~m}^{3} / \mathrm{d}$, respectively; the degree of mineralisation is $0.51 \mathrm{~g} / \mathrm{L}$ and $1.11 \mathrm{~g} / \mathrm{L}$, respectively. One is freshwater, and another is slightly saline.

Hydrochemical types are mainly $\mathrm{HCO}_{3}-\mathrm{Ca} \cdot \mathrm{Mg}$ and $\mathrm{HCO}_{3}-\mathrm{Ca} \cdot \mathrm{Na}$, with salinity of $0.35-0.66 \mathrm{~g} / \mathrm{L}$. They all yield fresh water, but some contain $\mathrm{SO}_{4} \cdot \mathrm{HCO}_{3}-\mathrm{Na} \cdot \mathrm{Ca}$, with a salinity of $1.11 \mathrm{~g} / \mathrm{L}$. The depth to the water level is mostly less than $5 \mathrm{~m}$ (some are artesian and can be as deep as 10-20 m).

Qiugang Quaternary System cover subzone $\left(\mathrm{III}_{5}{ }^{2}\right)$ is mainly distributed in the east side of Shiwu Lake, Tianshengqiao River, and Xinqiao River downstream with a total area of $125 \mathrm{~km}^{2}$. The surface layer covers Quaternary System soil with thickness of about $10 \mathrm{~m}$. The upper part is mainly subclay, and the lower part has a thin layer of sand. It is estimated that the maximum water volume of single well is $10-100 \mathrm{~m}^{3} / \mathrm{d}$, and the water table depth is less than $5 \mathrm{~m}$. The lower part of the cover layer is still Jurassic volcanic rocks and volcanic clastic rocks. The hydrogeological characteristics are similar to those of the exposed subzone of Qiugang bedrock $\left(\mathrm{III}_{5}{ }^{1}\right)$.

The groundwater of the landfill mainly belongs to pore phreatic water and bedrock fracture water. The phreatic water is stored in the layer (1). It mainly receives atmospheric precipitation and surface water recharge. The runoff is sluggish, mainly via evaporation and discharge, and the water level dynamics are influenced by seasonal changes with a strong connection between surface water and groundwater.
The depth to the groundwater level is $4.2-8.5 \mathrm{~m}$. The average elevation is $26.0 \mathrm{~m}$, and the annual variation of groundwater level is about $1.0 \mathrm{~m}$. The water richness of bedrock fracture water is shown to be uneven.

2.3.3. Recharge and Discharge of Groundwater. The sources of groundwater recharge are mainly vertical recharge and lateral recharge. The vertical recharge mainly comes from atmospheric precipitation infiltration with an average rainfall of $1204.3 \mathrm{~mm} / \mathrm{a}$. There is a long rainy season in summer, and rainfall is the main source of groundwater recharge. The groundwater level is closely related to the incident precipitation. With the increase of precipitation, the groundwater level rises; with the decrease of precipitation, the groundwater level falls. The recharge and runoff discharge conditions of the fractured clastic rock aquifer are significantly controlled by the terrain and the thickness of the residual soil of the Quaternary System. It receives direct recharge from atmospheric precipitation at the exposed bedrock and the thin thickness of the loose coverage layer on the mountain slope. The discharge patterns include evaporation and surface runoff. Meteorological data show that the average annual evaporation is $1287 \mathrm{~mm} / \mathrm{a}$, although the evaporation of groundwater is related to the depth to groundwater and the evaporation limiting depth is $5 \mathrm{~m}$. Beyond this depth, the effect of evaporation can be ignored, and the actual evaporation of groundwater is much smaller than the evaporation of surface water. The second means of groundwater discharge is mainly via flow to surface ponds, lakes, and rivers. The contour map of groundwater levels in the study area is shown in Figure 4.

\section{Methods}

\subsection{Mathematical Models of Groundwater Flow and Solute Transport}

3.1.1. Model of Groundwater Flow. The transient groundwater flow in heterogeneous anisotropic fractured media can be simulated using the Boussinesq equation:

$$
\left\{\begin{array}{l}
\mu \frac{\partial h}{\partial t}=\frac{\partial}{\partial x}\left(K_{x} \frac{\partial h}{\partial x}\right)+\frac{\partial}{\partial y}\left(K_{y} \frac{\partial h}{\partial y}\right)+\frac{\partial}{\partial z}\left(K_{z} \frac{\partial h}{\partial z}\right)+W, x, y, z \in \Omega, t \geq 0, \\
\left.h(x, y, z, t)\right|_{t=0}=h_{0}, x, y, z \in \Omega, \\
\left.h(x, y, z, t)\right|_{\Gamma_{1}}=h_{1}(x, y, z, t), x, y, z \in \Gamma_{1}, t \geq 0, \\
\left.K_{n} \frac{\partial h}{\partial \vec{n}}\right|_{\Gamma_{2}}=q(x, y, z, t), x, y, z \in \Gamma_{2}, t \geq 0,
\end{array}\right.
$$

where $x, y$, and $z$ are the spatial coordinates, $t$ is time, $\Omega$ is domain of fractured media, and $\Gamma_{1}$ and $\Gamma_{2}$ are the domains of the first and second type boundary, respectively. $h_{f}$ is the hydraulic head in the fractured system, $K_{x}, K_{y}$, and $K_{z}$ refer to the hydraulic conductivities along coordinate three axes, $\mu$ is the specific yield for unconfined aquifer and 


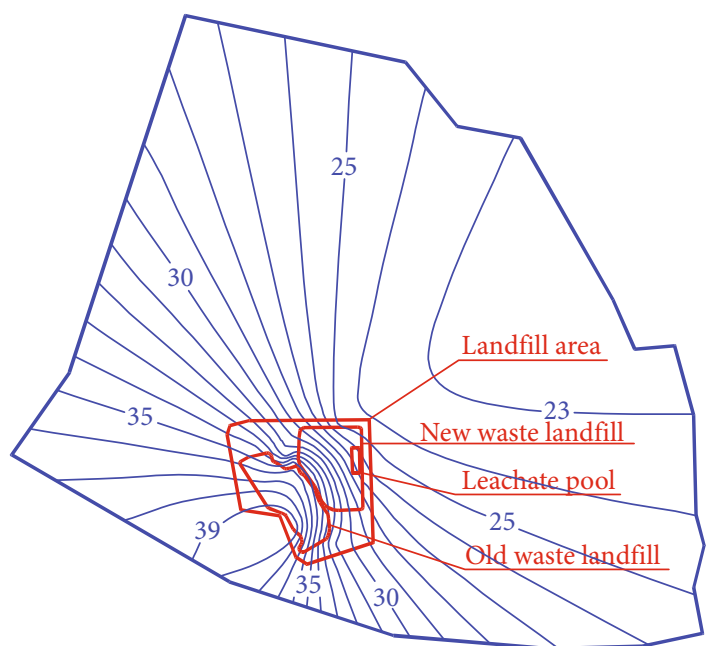

— Groundwater level

FIgURe 4: Contour map of groundwater levels.

specific storage for confined aquifer, $W$ represents the sinks and sources, such as the evaporation, precipitation, and pumping rate; $h_{0}$ is the initial groundwater table, $h_{1}$ denotes the known groundwater table in the first type boundary, $n$ is the normal direction of boundary surface, $K_{n}$ is the hydraulic conductivity in normal direction of boundary surface, and $q$ represents the unit area flux of the second type boundary, and its value is positive for groundwater inflow and negative for outflow.

3.1.2. Model of Solute Transport. The contaminant control equation can be expressed as follows:

$$
\begin{cases}R \theta \frac{\partial C}{\partial t}=\frac{\partial}{\partial x_{i}}\left(\theta D_{i j} \frac{\partial C}{\partial x_{j}}\right)-\frac{\partial}{\partial x_{i}}\left(\theta v_{i} C\right) & -W C_{s}-W C-\lambda_{1} \theta C-\lambda_{2} \rho_{b} \bar{C} \\ C(x, y, z, t)=C_{0}(x, y, z) & (x, y, z) \in \Omega, t=0, \\ \left.C(x, y, z, t)\right|_{\Gamma_{1}}=C(x, y, z, t) & (x, y, z) \in \Gamma_{1}, t \geq 0, \\ \left.\theta D_{i j} \frac{\partial C}{\partial x_{j}}\right|_{\Gamma_{2}}=f_{i}(x, y, z, t) & (x, y, z) \in \Gamma_{2}, t>0,\end{cases}
$$

where $R$ denotes the hysteresis coefficient, dimensionless; $\rho_{b}$ is the density of the medium; $\theta$ is its dimensionless porosity; $C$ is the component concentration; $\bar{C}$ represents the solute concentration adsorbed by the medium skeleton; $t$ is the time; $D_{i j}$ is the hydrodynamic dispersion coefficient tensor; $v_{i}$ is the groundwater percolation velocity tensor; $W$ refers to the source-sink term of water flow; $C_{s}$ stands for the concentration of the component; $\lambda_{1}$ is the primary reaction rate of the dissolved phase; $\lambda_{2}$ is the reaction rate of the adsorbed phase; $C_{0}(x, y, z)$ is the known concentration distribution; $\Omega$ denotes the model simulation area; $\Gamma_{1}$ is the given concentration boundary; $C(x, y, z, t)$ indicates the concentration distribution on the fixed concentration boundary; $\Gamma_{2}$ is the flux boundary; $f_{i}(x, y, z, t)$ is the known dispersion flux function on the boundary.

3.2. Determination of Hydraulic Conductivity. The methods to determine the hydraulic conductivity based on the data of water injection are mainly the Cooper-BredehoeftPapadopulos (CBP) model and Bouwer and Rice (BR) model, where the CBP model is applicable to confined aquifers and the BR model is mainly used for unconfined aquifers. Since the shallow groundwater in this study area is mainly pore phreatic water, the BR model is used to ascertain the hydraulic conductivity. Bouwer and Rice [30] proposed a method to obtain the hydraulic conductivity for submerged aquifers with intact or incomplete wells, which was not only similar to the Hvorslev method but also included a set of curves to determine the radius of influence. During a slug test, the change in the well is expressed as follows:

$$
\frac{d y(t)}{d t}=\frac{Q}{\pi r_{c}^{2}}
$$

where $Q$ represents instantaneous injection or withdrawal of water into the well and $y(t)$ is the change in water level at $t$. In the steady state, the flow rate can be expressed as follows:

$$
Q=2 \pi K L_{e} \frac{y}{\ln \left(R_{e} / r_{w}\right)},
$$

where $K$ is the hydraulic conductivity of aquifer, $L_{e}$ is the filter length, $R_{e}$ is the radius of influence, and $r_{w}$ is the radius of well or filter.

Substituting Equation (4) into Equation (3) and integrating it, an expression for the hydraulic conductivity is obtained:

$$
K=\frac{r_{c}^{2} \ln \left(R_{e} / r_{w}\right)}{2 L_{e}} \frac{1}{t} \ln \frac{y_{0}}{y},
$$

where $y_{0}$ is the initial water level change and $\ln \left(R_{e} / r_{w}\right)$ can be expressed using the following empirical equation:

$$
\ln \frac{R_{e}}{r_{w}}=\left[\frac{1.1}{\ln \left(L_{w} / r_{w}\right)}+\frac{A+B \ln \left[\left(D-L_{w}\right) / r_{w}\right]}{L_{e} / r_{w}}\right]^{-1},
$$

where $L_{w}$ is the distance between the bottom of the well and the initial water level, $A$ and $B$ depend on the ratio of $L_{e} / r_{w}$ (Figure 5), and $D$ refers to the distance between the bottom of the aquifer and the initial water level. When $L_{\mathrm{w}}=H$, Equation (6) can be simplified; thus,

$$
\ln \frac{R_{e}}{r_{w}}=\left[\frac{1.1}{\ln \left(L_{w} / r_{w}\right)}+\frac{C}{L_{e} / r_{w}}\right]^{-1},
$$

where $C$ denotes the function of $L_{e} / r_{w}$ (Figure 5). 


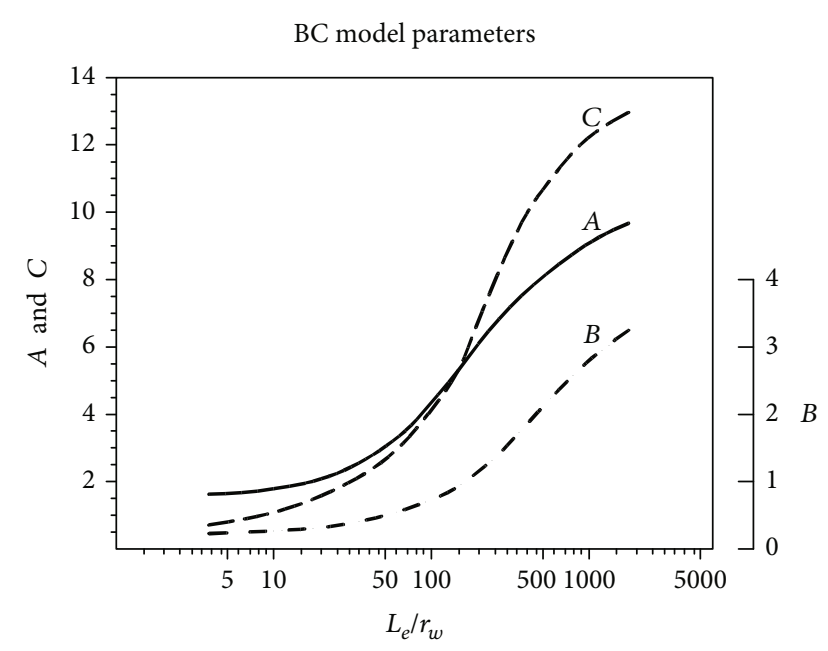

Figure 5: Relationship between dimensionless parameters $A, B$, and $C$ and $L_{e} / r_{w}$.

3.3. Vertical Hydraulic Conductivity of the Low Permeability Layer for the Riverbed. To determine the vertical hydraulic conductivity of the riverbed bottom deposit, a vertical tube is driven vertically into the riverbed sediment (Figure 6). It is usually measured by the artificial gradient method, where water is first added to the vertical tube, the hydraulic head at the corresponding time in the tube is measured, and then, the drop in water level is calculated. If there is an obvious difference between the river water stage and the groundwater level, the head of water in the pipe will be higher or lower than that outside the pipe (i.e., the river level); at this time, the falling or rising value of the water head in the pipe can be measured, which is the natural gradient method. The vertical pipe test is a polyvinyl chloride (PVC) pipe, with a length of $2 \mathrm{~m}$. The straight pipe of the test is used to determine the vertical direction of the hydraulic conductivity. Due to the vertical pipe test lasted a long time, to ensure that the water level in the vertical pipe will not be caused by changes in other conditions which may give rise to inaccurate data, the top of the vertical pipe with a film is sealed to prevent evaporation or rainfall.

According to Chen [31], the vertical hydraulic conductivity $\left(K_{v}\right)$ is calculated by using the following equation:

$$
K_{\mathrm{v}}=\frac{L_{V}}{t_{2}-t_{1}} \ln \frac{h_{1}}{h_{2}},
$$

where $K_{v}$ is the vertical hydraulic conductivity of the riverbed, $L_{v}$ represents the length of the riverbed sediment in the measurement tube, and $h_{1}$ and $h_{2}$ denote the groundwater level values at tines $t_{1}$ and $t_{2}$ in the measurement tube, respectively. The river water level is considered as a constant during the test.

3.4. Parameter Calibration. A least-squares method (LSM) is employed to calibrate the hydraulic conductivity. A general,

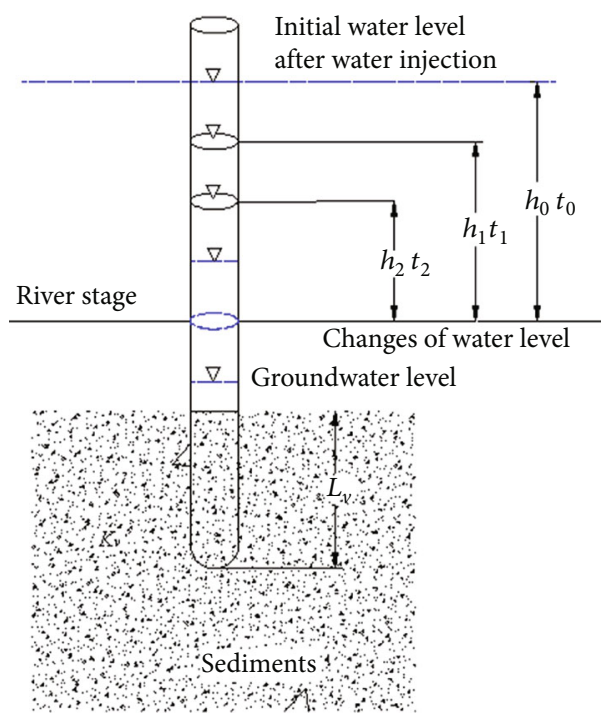

FIgURE 6: Schematic diagram of a standpipe test.

the function of LSM for a transient flow can be expressed as follows [32]:

$$
\operatorname{LSM}=\sum_{j=1}^{m} \sum_{i=1}^{n} w_{i, j}\left[\left(h_{O}-h_{c}\right)_{i, j}\right]^{2},
$$

where $m$ is the number of time steps, $n$ denotes the number of given hydraulic heads, $h_{O}$ and $h_{c}$ are the observed and calculated groundwater tables, respectively, and $w_{i, j}$ are weighting factors, which range from 0 to 1 . Their value depends on location of the observation holes. For high groundwater tables, a small weight is assigned; otherwise, the weight has a large value. When the value of LSM is less than a given predetermined error, the calibrated parameters are deemed optimal.

3.5. Numerical Simulation Method. The software FEFLOW (Finite Element Subsurface Flow System), which is a numerical simulation developed by the German WASY Water Resources Planning and Systems Research Institute in the late 1970s, is employed to simulate the groundwater flow and contaminant migration in the study area. The software is one of the most complete groundwater simulation software packages so far. It demonstrates the characteristics of fast and accurate numerical method, advanced graphic visualisation technology, etc. It can simulate the migration process of contaminants in groundwater and its time and space distribution.

\section{Results and Discussion}

\subsection{Field Tests and Parameter Determination}

4.1.1. Water Injection Test. The lithology of the study area is mainly clay with pebble gravel and strongly and moderately weathered breccia. The stratigraphy revealed by the boreholes shows that the lithology at each monitoring well is similar, and the aquifers are all phreatic aquifers, which are 
TABLE 1: Calculation results of hydraulic conductivity of some boreholes.

\begin{tabular}{|c|c|c|c|c|c|c|c|c|c|c|}
\hline No. & $\begin{array}{l}\text { Burial depth } \\
\text { before water } \\
\text { injection }(\mathrm{m})\end{array}$ & $\begin{array}{l}\text { Height after } \\
\text { water } \\
\text { injection }(\mathrm{m})\end{array}$ & $\begin{array}{l}\text { Time } \\
(\mathrm{s})\end{array}$ & $\begin{array}{c}\text { Water level } \\
\text { height at } \\
\text { time } t(\mathrm{~m})\end{array}$ & $\begin{array}{c}\text { Screen } \\
\text { length }(\mathrm{m})\end{array}$ & $\begin{array}{l}\text { Casing radius } \\
(\mathrm{m})\end{array}$ & $\begin{array}{l}\text { Borehole } \\
\text { depth }(m)\end{array}$ & $L_{w}=H /(\mathrm{m})$ & $D(\mathrm{~m})$ & $\begin{array}{c}\text { Hydraulic } \\
\text { conductivity } \\
(\mathrm{cm} / \mathrm{s})\end{array}$ \\
\hline GW3 & 8.30 & 0.82 & 2030 & 0.79 & 4 & 0.055 & 10 & 8.8 & 19.2 & $2.42 \times 10^{-6}$ \\
\hline GW5 & 7.51 & 4.39 & 950 & 4.31 & 4 & 0.055 & 10 & 9.27 & 19.2 & $2.85 \times 10^{-6}$ \\
\hline GW6 & 4.67 & 2.74 & 2015 & 1.92 & 4 & 0.055 & 8 & 5.21 & 19.2 & $2.65 \times 10^{-5}$ \\
\hline GW10 & 7.91 & 5.29 & 1520 & 5.15 & 4 & 0.055 & 27 & 2.64 & 19.2 & $5.15 \times 10^{-6}$ \\
\hline
\end{tabular}

TABLE 2: Hydraulic conductivity of riverbed sediments.

\begin{tabular}{lcccc}
\hline Test location & Time $(\mathrm{s})$ & Water level $(\mathrm{cm})$ & Hydraulic conductivity $(\mathrm{cm} / \mathrm{s})$ & Average hydraulic conductivity $(\mathrm{cm} / \mathrm{s})$ \\
\hline & 0 & 166 & - & $3.89 \times 10^{-6}$ \\
Vertical pipe 1 & 9300 & 165.7 & $3.72 \times 10^{-6}$ & $3.18 \times 10^{-6}$ \\
& 12,960 & 165.6 & $1.93 \times 10^{-6}$ & - \\
& 68,820 & 164.9 & $2.97 \times 10^{-6}$ & $3.18 \times 10^{-6}$ \\
Vertical pipe 2 & 0 & 158 & $2.10 \times 10^{-6}$ & $1.74 \times 10^{-6}$ \\
& 8940 & 157.8 & 157.7 & \\
\hline
\end{tabular}

divided into three layers. Based on the field water injection test data, the BR model is utilised to calculate the hydraulic conductivity of the phreatic aquifer (Table 1); the difference in hydraulic conductivity is about one order of magnitude due to the heterogeneity and anisotropy of the fractured rock mass.

4.1.2. Standpipe Tests. In this study, the artificial gradient method was used to solve the hydraulic conductivity. Two PVC pipes with a length of $2 \mathrm{~m}$, an inner diameter of $46 \mathrm{~mm}$, and an outer diameter of $50 \mathrm{~mm}$ were selected. The PVC pipes were inserted on the Xinmo River, which was located $1 \mathrm{~km}$ to the west of the landfill site (called vertical pipes 1 and 2). Among them, the latitude of vertical pipe 1 is $31^{\circ} 39^{\prime} 37.96^{\prime \prime} \mathrm{N}$ and the longitude is $118^{\circ} 59^{\prime} 28.77^{\prime \prime} \mathrm{E}$. The latitude of vertical pipe 2 is $31^{\circ} 39^{\prime} 37.62^{\prime \prime} \mathrm{N}$, and the longitude is $118^{\circ} 59^{\prime} 28.07^{\prime \prime} \mathrm{E}$. The thicknesses of riverbed sediment in vertical pipe 1 and vertical pipe 2 are $0.20 \mathrm{~m}$ and $0.21 \mathrm{~m}$, and the distances between river water level and the pipe orifices are $1.66 \mathrm{~m}$ and $1.58 \mathrm{~m}$. The pipes were covered with PVC pipe cover to prevent intrusion of rainwater. The water level corresponding to different times was recorded. Any two water head values and corresponding time were used to calculate the hydraulic conductivity of sediments in the measuring pipe. The observed values and calculation results of hydraulic conductivity of riverbed sediments are listed in Table 2 . The calculation results show that there is a certain hydraulic connection between groundwater and surface water in the area.

4.1.3. Determination of the Diffusion Coefficient. Makuch [33] synthesised the available research: the extent of varia- tions in the media under different lithologies and different scale conditions was ascertained statistically. The longitudinal dispersion of contaminant migration in different lithologies under the phenomenon of the scale effect was obtained. According to laboratory dispersion tests and in situ measurements (Lishui Shiqiu and Zhetang), the extent of longitudinal dispersion was taken as $50 \mathrm{~m}$ and that in the transverse direction was taken as $5 \mathrm{~m}$ for the phreatic aquifer in this study area.

4.2. Hydraulic Conductivities of Fracture Media by Inversion Method. The groundwater type in the study area is phreatic water. According to the disclosed stratum, it is divided into three layers on the cross section: clay with gravel, strongly weathered and moderately weathered breccia layers, and the weakly weathered breccia layer at the bottom is a water-resistant layer. The average depth is $30 \mathrm{~m}$. Since the east, west, and north sides of the study area are relatively large rivers, these three sides are generalised as the first type of boundary, that is, a boundary with a fixed head of water. The weakly weathered breccia layer at the bottom of the phreatic aquifer exhibits good integrity and can be used as a water-resisting boundary. Therefore, the hydrogeological conceptual model is obtained in the study area.

The calculation area takes the central of the project site as the coordinate origin. The due north direction, east direction, and the vertical direction are the $y$-axis positive direction, $x$-axis positive direction, and the $z$-axis positive direction: seven layers are considered vertically. The study area is discretised into 143,976 nodes and 244,566 units (Figure 7). 


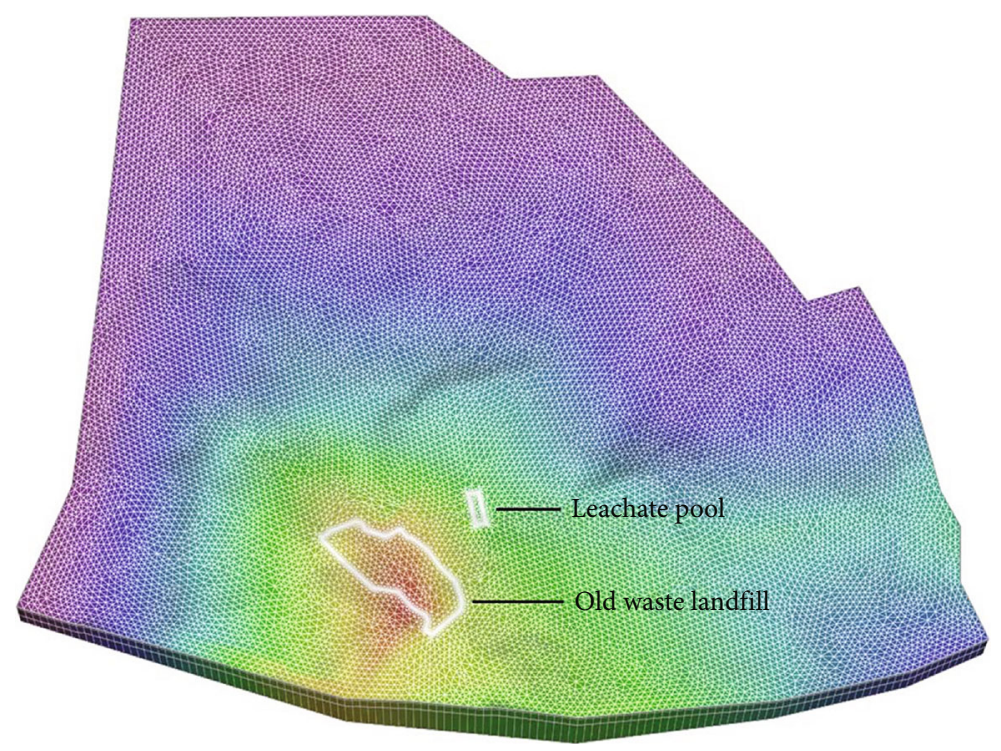

FIGURE 7: Mesh map of the study area.

TABLE 3: Inversion values of the hydraulic conductivity for the aquifer.

\begin{tabular}{|c|c|c|c|c|c|}
\hline \multirow{2}{*}{ Layer number } & \multirow{2}{*}{ Geotechnical type } & \multirow{2}{*}{ Thickness (m) } & \multicolumn{3}{|c|}{ Hydraulic conductivity $(\mathrm{m} / \mathrm{d})$} \\
\hline & & & $K_{x}$ & $K_{y}$ & $K_{z}$ \\
\hline (2) & Clay with pebbles and gravel & $3.4-16.5$ & 0.98 & 0.86 & 0.088 \\
\hline (3) 1 & Strongly weathered breccia & $0.6-1.5$ & 0.56 & 0.48 & 0.045 \\
\hline (3) 2 & Moderately weathered breccia & $5.3-24.7$ & 0.082 & 0.078 & 0.0075 \\
\hline
\end{tabular}

The study area is a relatively independent hydrogeological unit. The east, west, and north boundaries are rivers, which can be regarded as constant-head boundaries. The south side is the no-flow boundary, and the bottom of the aquifer is the other no-flow boundary. The top is recharged from precipitation, and the discharge is mainly by evaporation. The water level of the monitoring hole in the simulation area is taken as the initial water level of the simulation prediction. The background value of the concentration of the current groundwater monitoring is the initial value; the initial time is December 2020.

4.2.1. Model Parameter Identification. To verify the reasonableness and validity of the model, it is necessary to identify the parameters of the numerical model for ensuring that the model can accurately reflect the hydrogeological conditions in the evaluation area. Each hydrological parameter obtained from the field test is used as the initial value of the model parameters (Table 1). The model parameters are repeatedly adjusted by comparing the calculated and measured water levels in 10 observation boreholes to obtain the best fitting results. The final values of each calculated parameter of the model are listed in Table 3, and the results of groundwater level fitting are illustrated in Figure 8; except for certain differences in GW6, the calculated water levels are in good agreement with the measured water levels, suggesting that the model parameters are reasonable and the identified numerical model can be used for the simulation and predic- tion of groundwater flow movement and contaminant migration in the site.

\subsection{Prediction and Simulation of Contaminant Migration}

4.3.1. Analysis of Potential Pollution Sources for Groundwater. According to the engineering analysis and construction characteristics of the project, the risk sources of groundwater pollution are mainly leachate collection pools of the old landfill and the new landfill. The waste water generated by the project is mainly ground flushing water, vacuum system waste water, and domestic sewage with a volume of $33,320 \mathrm{~m}^{3} / \mathrm{a}$. The old landfill used to have no antiseepage measures, but now a vertical antiseepage wall, has been installed. During the period of its operation, waste water mainly comes from landfill leachate, ground flushing water, and domestic sewage. Due to the incomplete drainage system, the disorderly and scattered discharge of waste water may seep into the ground and then pollute the groundwater. After closure of the site, the main source of risk of groundwater pollution is landfill leachate. The main contaminants are ammonia nitrogen and mercury. When the vertical antiseepage walls are in place and the sewage pipeline operates normally, the possibility of sewage leakage is very small, and the surrounding of the landfill will not be contaminated. The leachate will seep into the ground below to the water barrier. Under abnormal working conditions, including failure of sewage equipment, rupture of sewers, or 


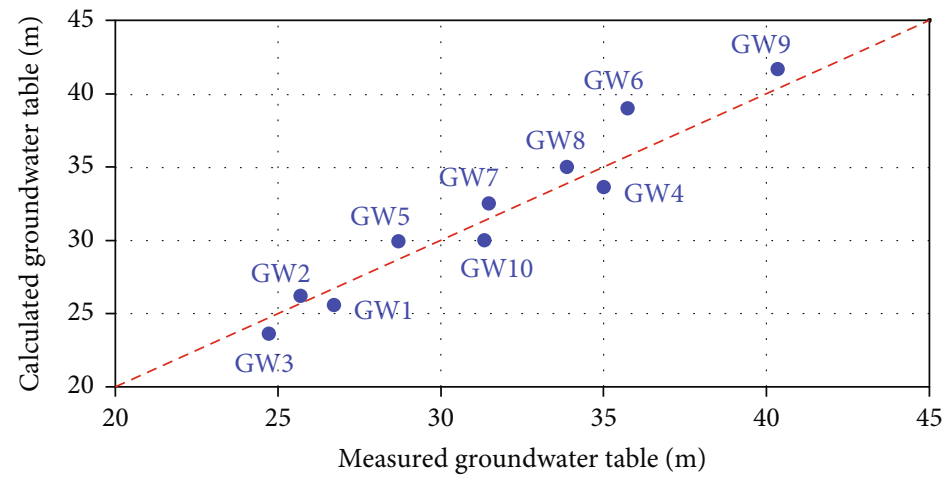

- GW

Groundwater level observation

Water level fitting line

FIGURE 8: Comparison of measured and fitted water levels.

TABLE 4: Characteristics of contaminant migration in the old landfill.

\begin{tabular}{|c|c|c|c|c|}
\hline Transport time $(\mathrm{d})$ & Contaminants & Conditions of seepage control & Maximum migration distance $(\mathrm{m})$ & Contamination range $\left(\mathrm{m}^{2}\right)$ \\
\hline \multirow{4}{*}{100} & \multirow{2}{*}{ Ammonia nitrogen } & Normal conditions & 0.88 & 54773.18 \\
\hline & & Seepage control failure & 15.64 & 66814.36 \\
\hline & \multirow{2}{*}{ Mercury } & Normal conditions & 0.43 & 54424.00 \\
\hline & & Seepage control failure & 1.47 & 52469.45 \\
\hline \multirow{4}{*}{1000} & \multirow{2}{*}{ Ammonia nitrogen } & Normal conditions & 1.95 & 55679.97 \\
\hline & & Seepage control failure & 40.88 & 97528.26 \\
\hline & \multirow{2}{*}{ Mercury } & Normal conditions & 0.84 & 54754.56 \\
\hline & & Seepage control failure & 4.06 & 58843.31 \\
\hline \multirow{4}{*}{1825} & \multirow{2}{*}{ Ammonia nitrogen } & Normal conditions & 2.82 & 56476.89 \\
\hline & & Seepage control failure & 74.94 & 114932.76 \\
\hline & \multirow{2}{*}{ Mercury } & Normal conditions & 1.08 & 54949.44 \\
\hline & & Seepage control failure & 8.85 & 59793.34 \\
\hline \multirow{4}{*}{3650} & \multirow{2}{*}{ Ammonia nitrogen } & Normal conditions & 3.67 & 57568.13 \\
\hline & & Seepage control failure & 92.30 & 153047.67 \\
\hline & \multirow{2}{*}{ Mercury } & Normal conditions & 1.50 & 55438.04 \\
\hline & & Seepage control failure & 13.87 & 65495.72 \\
\hline \multirow{4}{*}{7300} & \multirow{2}{*}{ Ammonia nitrogen } & Normal conditions & 4.92 & 58631.53 \\
\hline & & Seepage control failure & 113.89 & 185814.18 \\
\hline & \multirow{2}{*}{ Mercury } & Normal conditions & 2.09 & 55830.36 \\
\hline & & Seepage control failure & 35.43 & 85631.70 \\
\hline
\end{tabular}

cracking and leakage of the antiseepage wall, the sewage pool (station) will cause point or surface source pollution to the groundwater: contaminants may seep down to the vadose zone and then be transported through the phreatic aquifer. Therefore, this study mainly considers the migration pattern of contaminants in the aquifer under abnormal working conditions (failure of sewage equipment, rupture of sewers, or cracking of treatment ponds, leakage, failure of antiseepage measures, etc.). The standard index method is used to evaluate the impact of groundwater quality of the project, in which ammonia nitrogen and mercury are referred to Groundwater Quality Standard GB/T14848-2017.

4.3.2. Simulation of Contaminant Migration in the Old Waste Landfill. The main contaminant of the old landfill is landfill leachate, which is distributed at the bottom of the whole landfill due to the absence of horizontal antiseepage measures. The calculation results show that, considering vertical antiseepage measures, the maximum migration distance of contaminants is $4.92 \mathrm{~m}$ at 20 years postclosure (Table 4 ), and the extent of the pollution is very small. If abnormal 


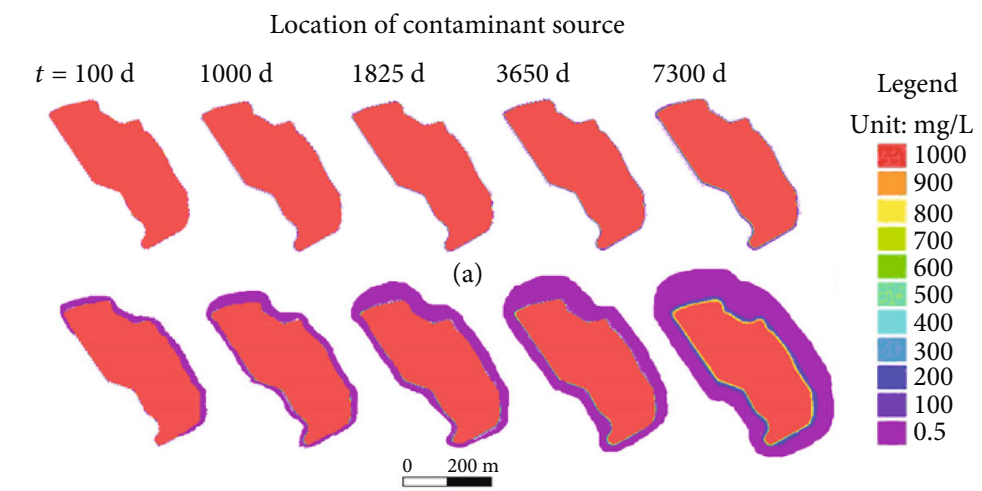

(b)

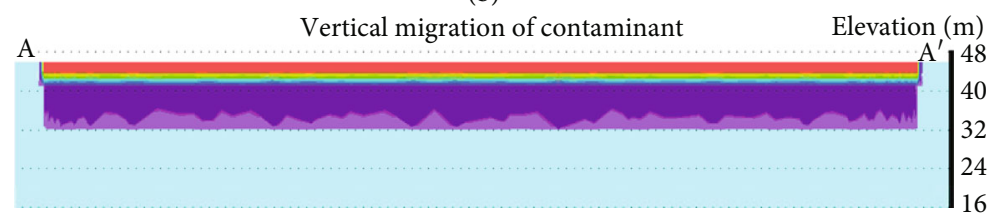

(c)

FIGURE 9: Ammonia nitrogen migration maps of the old waste landfill: (a) under normal conditions of seepage control, (b) under conditions of seepage control failure, and (c) 20 years of profile migration under normal conditions.

conditions occur, such as cracked vertical antiseepage walls, the waste water will leak. In the worst case, the waste water will be discharged continuously with the influent concentration and then pollute the groundwater. The migration characteristics of contaminants under abnormal conditions are displayed in Table 4 . The contaminated area refers to the total area of groundwater contaminated (including the area of contamination sources), which is determined by the class III standard of groundwater. The water quality in the contaminated area is poor and lower than the class III water standard.

4.3.3. Ammonia Nitrogen. The initial concentration of ammonia nitrogen in the leachate is $1000 \mathrm{mg} / \mathrm{L}$ in the old landfill. The calculation results imply that under normal working conditions, the maximum migration distance of the old landfill contaminant source is about $4.92 \mathrm{~m}$ after 20 years. The total area contaminated on the plane is $58,631.53 \mathrm{~m}^{2}$, and the range of diffusion of contaminants is shown in Figure 9(a). The impact depth of contaminants on the profile reaches the bottom of the aquifer after 20 years (Figure 9(b)). This indicates that under normal conditions, the impact of contaminants in the horizontal direction is small, but the vertical influence is greater, because there is no horizontal antiseepage system installed. If the vertical antiseepage measures in the old landfill fail locally in the study area, the maximum migration distances of the contaminant source are about $15.64 \mathrm{~m}$ at 100 days, $53.88 \mathrm{~m}$ at 1000 days, and $113.89 \mathrm{~m}$ at 20 years: the total areas contaminated on the plane are $66,814.36 \mathrm{~m}^{2}, 105,284.26 \mathrm{~m}^{2}$, and $85814.18 \mathrm{~m}^{2}$. The range of contaminant diffusion is demonstrated in Figure 9(c). Under the condition of antiseepage measure failing, contaminants in groundwater diffuse widely in a very short time; therefore, the integrity of the vertical antiseepage wall should be checked regularly after the closure of the study area. If the performance is found to be reduced, the antiseepage system should be reinforced timeously.

4.3.4. Mercury. The initial concentration of mercury in the leachate is $0.004 \mathrm{mg} / \mathrm{L}$ in the landfill. From the plane, under the normal working conditions, the maximum migration distance of contaminants from the old landfill is about $2.09 \mathrm{~m}$ after 20 years. The total area contaminated on the plane is $55830.36 \mathrm{~m}^{2}$, and the range of diffusion of contaminants is illustrated in Figure 10(a). The depth of influence of contaminants on the profile is about $1.98 \mathrm{~m}$ after 20 years (Figure 10(b)). Due to the low initial concentration, the distance of contaminants migrating on both plane and profile is small. Under the condition of low-permeability performance of vertical antiseepage wall, the maximum migration distances of contaminants in the study area location are about $1.47 \mathrm{~m}$ in 100 days, $4.06 \mathrm{~m}$ in 1000 days, and $35.43 \mathrm{~m}$ in 20 years; the total areas contaminated on the plane are $52,469.45 \mathrm{~m}^{2}, 58,843.31 \mathrm{~m}^{2}$, and $85631.70 \mathrm{~m}^{2}$. The scope of contaminant diffusion is shown in Figure 10(c); when the permeability of the antiseepage wall increases, the contaminant diffusion in groundwater increases rapidly, and the antiseepage treatment of the landfill should be strengthened.

4.3.5. Simulation of Contaminant Migration in the New Waste Landfill. The main contaminant of the new landfill is landfill leachate. There is a leachate collection pond next to the landfill, and this is horizontally impermeable. The calculated results show that the maximum migration distance of contaminants is $10.85 \mathrm{~m}$ after 20 years of project operation (Table 5), and the migration distance of contaminants is small. In case of abnormal working conditions, such as cracking of the antiseepage system of the treatment tank, the waste water will leak. The worst case is that the waste water will maintain the influent concentration and discharge continuously and then pollute the groundwater. Under 


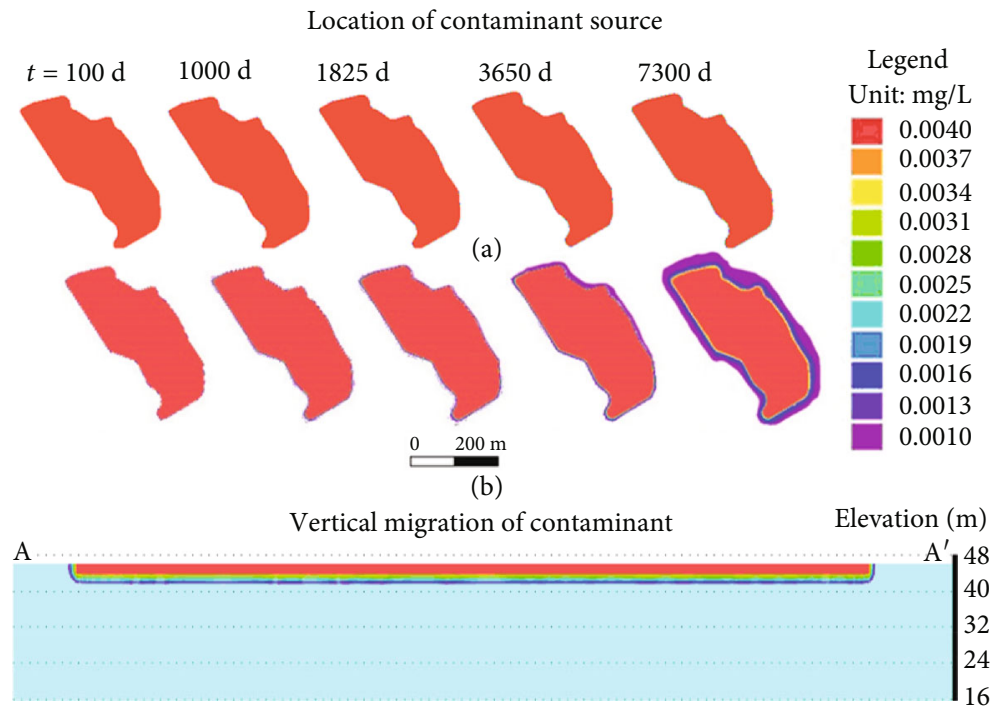

(c)

Figure 10: Mercury migration maps of the old waste landfill: (a) under normal conditions of seepage control, (b) under conditions of seepage control failure, and (c) 20 years of profile migration under normal conditions.

TABLE 5: Characteristics of contaminant migration in the new landfill leachate pool.

\begin{tabular}{|c|c|c|c|c|}
\hline Transport time $(\mathrm{d})$ & Contaminants & Conditions of seepage control & Maximum migration distance $(\mathrm{m})$ & Contamination range $\left(\mathrm{m}^{2}\right)$ \\
\hline \multirow{4}{*}{100} & \multirow{2}{*}{ Ammonia nitrogen } & Normal conditions & 0.98 & 2679.08 \\
\hline & & Seepage control failure & 7.66 & 2494.59 \\
\hline & \multirow{2}{*}{ Mercury } & Normal conditions & 0.26 & 2469.29 \\
\hline & & Seepage control failure & 3.5 & 2433.40 \\
\hline \multirow{4}{*}{1000} & \multirow{2}{*}{ Ammonia nitrogen } & Normal conditions & 4.64 & 3330.36 \\
\hline & & Seepage control failure & 79.4 & 3388.45 \\
\hline & \multirow{2}{*}{ Mercury } & Normal conditions & 0.94 & 2632.68 \\
\hline & & Seepage control failure & 5.8 & 2490.51 \\
\hline \multirow{4}{*}{1825} & \multirow{2}{*}{ Ammonia nitrogen } & Normal conditions & 5.49 & 3624.70 \\
\hline & & Seepage control failure & 104.8 & 4162.88 \\
\hline & \multirow{2}{*}{ Mercury } & Normal conditions & 1.02 & 2680.14 \\
\hline & & Seepage control failure & 8.5 & 2562.82 \\
\hline \multirow{4}{*}{3650} & \multirow{2}{*}{ Ammonia nitrogen } & Normal conditions & 8.31 & 4158.72 \\
\hline & & Seepage control failure & 161.7 & 5016.18 \\
\hline & \multirow{2}{*}{ Mercury } & Normal conditions & 1.31 & 2712.98 \\
\hline & & Seepage control failure & 12.1 & 2662.27 \\
\hline \multirow{4}{*}{7300} & \multirow{2}{*}{ Ammonia nitrogen } & Normal conditions & 10.85 & 4762.93 \\
\hline & & Seepage control failure & 192.5 & 6216.45 \\
\hline & \multirow{2}{*}{ Mercury } & Normal conditions & 1.45 & 2736.74 \\
\hline & & Seepage control failure & 15.0 & 2758.13 \\
\hline
\end{tabular}

abnormal conditions, the migration characteristics of contaminants are listed in Table 5.

4.3.6. Ammonia Nitrogen. The initial concentration of ammonia nitrogen in the leachate is $1000 \mathrm{mg} / \mathrm{L}$ in the new landfill. Under normal working conditions, the maximum migration distance of the pollution source in the new landfill is about $10.85 \mathrm{~m}$ after 20 years, and the total area contaminated on the plane is $4762.93 \mathrm{~m}^{2}$. The range of diffusion of contaminants is shown in Figure 11(a). The impact depth of contaminants on the profile after 20 years is about $2.94 \mathrm{~m}$ (Figure 11(b)), and the migration distance of contaminants in the vertical direction is smaller. In case of an emergency, the horizontal antiseepage of the new landfill is 


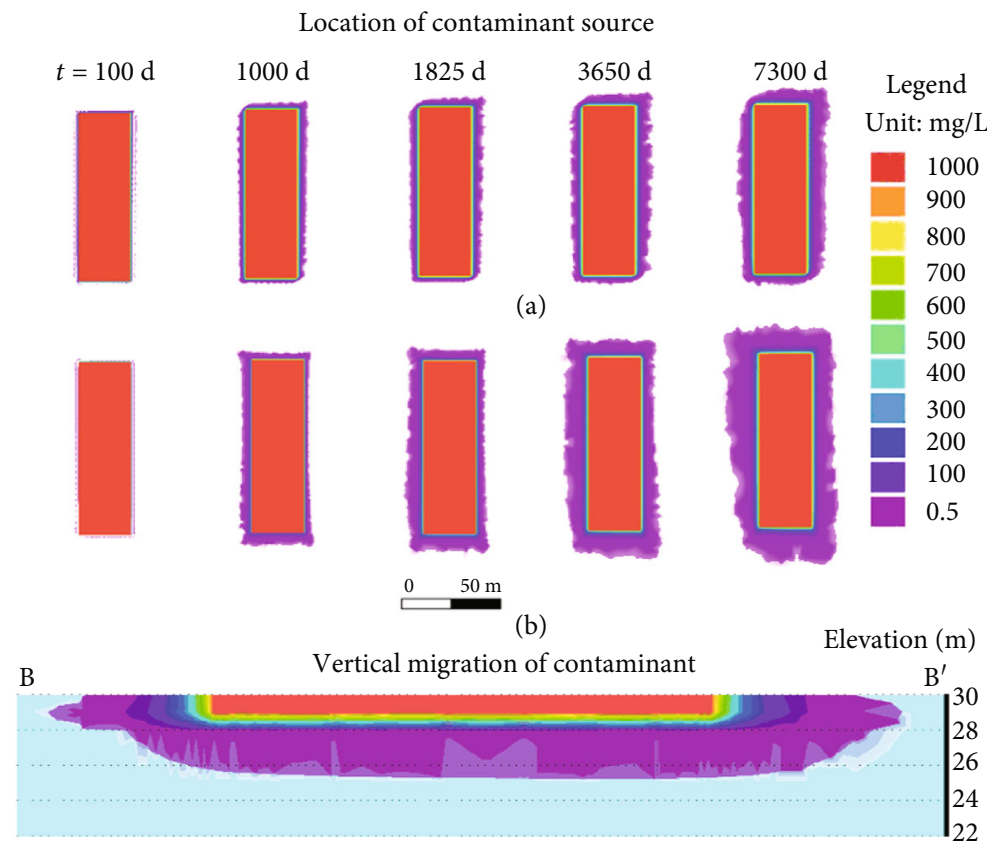

(c)

Figure 11: Ammonia nitrogen migration maps of the new waste landfill: (a) under normal conditions of seepage control, (b) under conditions of seepage control failure, and (c) 20 years of profile migration under normal conditions.

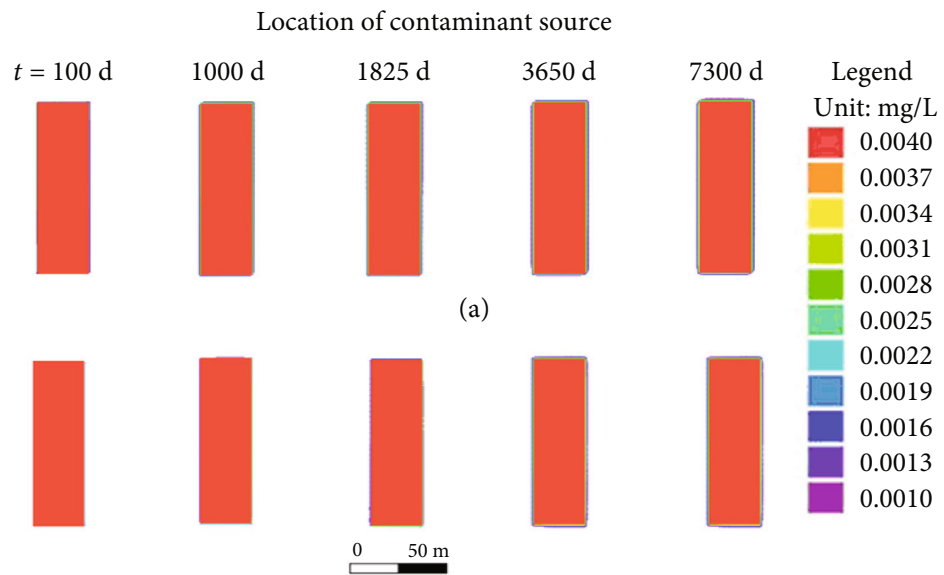

(b)

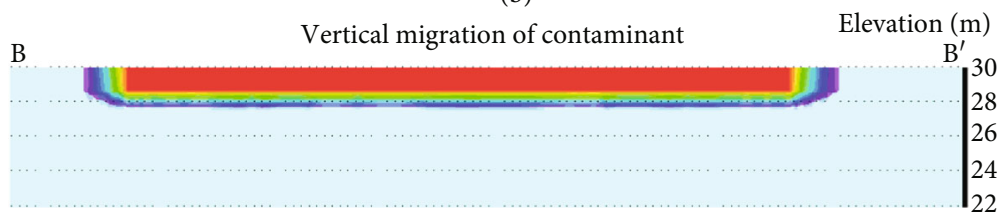

(c)

Figure 12: Mercury migration maps of the new waste landfill: (a) under normal conditions of seepage control, (b) under conditions of seepage control failure, and (c) 20 years of profile migration under normal conditions.

reduced. The maximum migration distances of the contaminant source at the project site are about $7.66 \mathrm{~m}$ at 100 days, $79.4 \mathrm{~m}$ at 1000 days, and $192.5 \mathrm{~m}$ at 20 years; the total areas polluted on the plane are $2494.59 \mathrm{~m}^{2}, 3388.45 \mathrm{~m}^{2}$, and $6216.45 \mathrm{~m}^{2}$. The scope of contaminant diffusion is displayed in Figure 11(c). The depth of influence in the vertical direction after 100 days is about $2.95 \mathrm{~m}$. Under the condition of a sudden accident, contaminants in groundwater diffuse over a large range in a very short time, so regular monitoring of groundwater should be strengthened.

4.3.7. Mercury. The initial concentration of mercury in the leachate is $0.004 \mathrm{mg} / \mathrm{L}$ in the new landfill. Under normal working conditions, the maximum migration distance of 
the pollution source in the new landfill is about $1.45 \mathrm{~m}$ after 20 years, and the total area contaminated on the plane is $2736.74 \mathrm{~m}^{2}$. The range of diffusion of contaminants is shown in Figure 12(a). After 20 years, the impact depth of contaminants on the profile is about $0.85 \mathrm{~m}$ (Figure 12(b)). Therefore, both on the plane and profile, the migration of mercury is minimal. In case of an emergency, the maximum migration distances of the contaminant source in the project site are about $3.5 \mathrm{~m}$ at 100 days, $5.8 \mathrm{~m}$ at 1000 days, and $15.0 \mathrm{~m}$ at 20 years. And the total areas contaminated on the plane are $2433.40 \mathrm{~m}^{2}, 2490.51 \mathrm{~m}^{2}$, and $2758.13 \mathrm{~m}^{2}$ (Figure 12(c)).

The above analysis shows that the vertical seepage interception measures around the landfill can control the horizontal diffusion of harmful substances in the landfill leachate; however, the retardation effect on the vertical diffusion of contaminants is small. Under the condition of reduced antiseepage performance, contaminants migrate far in the horizontal direction and migrate to the bottom of the aquifer in the vertical direction. The closure of the site has improved the site conditions of the landfill during the operation period and alleviated the problem of the migration and diffusion of contaminants that may occur in the later stage of the landfill.

\section{Conclusion}

Based on the investigation of the hydrogeological conditions and the current situation of groundwater environment around a municipal solid waste landfill in Lishui (Nanjing), the hydrogeological parameters of the study area are determined by means of in situ borehole water injection tests, permeability tests, and the inversion method. Combined with the characteristics of landfill leachate, ammonia nitrogen and mercury are selected as simulation factors to predict the spatiotemporal distribution characteristics of groundwater pollution, in the case of leakage from new and old landfill sites after their closure. According to the predicted results, a reasonable pollution prevention and control scheme is proposed to protect regional groundwater resources. The predictions suggest that under normal conditions, after 20 years, the maximum horizontal migration distances of contaminants from the old landfill and the new landfill are $4.92 \mathrm{~m}$ and $10.85 \mathrm{~m}$. The maximum vertical migration distance is about $10 \mathrm{~m}$. This result indicates that under normal conditions, the contaminants from the old landfill have little impact on the surrounding area, and the contaminants mainly migrate vertically downwards. Under abnormal conditions, when the vertical antiseepage wall of the old landfill and the impermeable leachate pond of the new landfill fail, the maximum migration distance of contaminants in the horizontal direction of the old landfill is about $15.64 \mathrm{~m}$ after 100 days, and the maximum migration distance is $113.89 \mathrm{~m}$ after 20 years. The maximum migration distance of contaminants in the horizontal direction of the new landfill is about $7.66 \mathrm{~m}$ after 100 days, and the maximum migration distance is $192.5 \mathrm{~m}$ after 20 years. This shows that under abnormal conditions, the migration of contaminants exerts a certain influence on groundwater. Therefore, the unexpected condi- tions should be managed timeously to avoid the expansion of the range of impact of the contaminants.

\section{Data Availability}

The data used to support the findings of this study are included within the article.

\section{Consent}

No consent was necessary.

\section{Conflicts of Interest}

The authors declare no conflict of interest.

\section{Authors' Contributions}

Conceptualisation was contributed by X.S. and Y.J.; methodology was contributed by Y.H.; software was contributed by Y.S.; validation was done by X.S., Y.J., Y.H., Y.S., and K.M.; formal analysis was contributed by K.M.; investigation was contributed by X.S. and Y.J.; resources were contributed by K.M.; data curation was contributed by Y.S.; writing original draft preparation was done by Y.J.; writing-review and editing was performed by Y.H. All authors have read and agreed to the published version of the manuscript.

\section{Acknowledgments}

This study was financially supported by the National Natural Science Foundation of China (Grant No. 41772235).

\section{References}

[1] A. Demirbas, R. H. Alamoud, W. Ahmad, and M. H. Sheıkh, "Optimization of municipal solid waste (MSW) disposal in Saudi Arabia," Energy Sources, Part A: Recovery, Utilization, and Environmental Effects, vol. 38, no. 13, pp. 1929-1937, 2016.

[2] A. Camba, S. González-García, A. Bala, P. Fullana-I-Palmer, M. T. Moreira, and G. Feijoo, "Modeling the leachate flow and aggregated emissions from municipal waste landfills under life cycle thinking in the Oceanic region of the Iberian Peninsula," Journal of Cleaner Production, vol. 67, pp. 98106, 2014.

[3] S. Kumar, N. Nimchuk, R. Kumar et al., "Specific model for the estimation of methane emission from municipal solid waste landfills in India," Bioresource Technology, vol. 216, pp. 981987, 2016.

[4] Productivity Commission, Waste Management-Productivity Commission Inquiry Report, Productivity Commission, Commonwealth of Australia, Canberra, 2006, May 2018, https:// www.pc.gov.au/_data/assets/pdf_file/0014/21614/waste.pdf.

[5] D. J. Lang, R. W. Scholz, C. R. Binder, A. Wiek, and B. Stäubli, "Sustainability Potential Analysis (SPA) of landfills - a systemic approach: theoretical considerations," Journal of Cleaner Production, vol. 15, no. 17, pp. 1628-1638, 2007.

[6] USEPA (United States Environmental Protection Agency), Municipal Solid Waste Generation, Recycling, and Disposal in the United States, Tables and Figures for 2012, USEPA, 
Washington, DC, 2012, May 2018, https:/www.epa.gov/sites/ production/files/2015-09/documents/2012_msw_dat_tbls .pdf.

[7] Y.-C. Weng, T. Fujiwara, H. J. Houng, C.-H. Sun, W.-Y. Li, and Y.-W. Kuo, "Management of landfill reclamation with regard to biodiversity preservation, global warming mitigation and landfill mining: experiences from the Asia-Pacific region," Journal of Cleaner Production, vol. 104, pp. 364-373, 2015.

[8] M. Bagheri, A. Bazvand, and M. Ehteshami, "Application of artificial intelligence for the management of landfill leachate penetration into groundwater, and assessment of its environmental impacts," Journal of Cleaner Production, vol. 149, pp. 784-796, 2017.

[9] U. Lee, J. Han, and M. Wang, "Evaluation of landfill gas emissions from municipal solid waste landfills for the life-cycle analysis of waste-to-energy pathways," Journal of Cleaner Production, vol. 166, pp. 335-342, 2017.

[10] L. Behrooznia, M. Sharifi, R. Alimardani, and S. H. MousaviAvval, "Sustainability analysis of landfilling and compostinglandfilling for municipal solid waste management in the north of Iran," Journal of Cleaner Production, vol. 203, pp. 10281038, 2018.

[11] DEE (Department of the Environment and Energy), National Waste Report, DEE. ACT, Australia, 2018, http://www .environment.gov.au/system/files/resources/7381c1de-31d0429b-912c-91a6dbc83af7/files/national-waste-report-2018 .pdf.

[12] P. Jain, J. T. Powell, J. L. Smith, T. G. Townsend, and T. Tolaymat, "Life-cycle inventory and impact evaluation of mining municipal solid waste landfills," Environmental Science \& Technology, vol. 48, no. 5, pp. 2920-2927, 2014.

[13] J. B. Christensen, D. L. Jensen, C. Grøn, Z. Filip, and T. H. Christensen, "Characterization of the dissolved organic carbon in landfill leachate-polluted groundwater," Water Research, vol. 32, no. 1, pp. 125-135, 1998.

[14] R. K. Rowe, "Long term performance of contaminant barrier systems," Geotechnique, vol. 55, no. 9, pp. 631-678, 2005.

[15] O. Ogundiran and T. Afolabi, "Assessment of the physicochemical parameters and heavy metals toxicity of leachates from municipal solid waste open dumpsite," International journal of Environmental Science and Technology, vol. 5, no. 2, pp. 243-250, 2008.

[16] D. S. Fernández, M. E. Puchulu, and S. M. Georgieff, “(2014). Identification and assessment of water pollution as a consequence of a leachate plume migration from a municipal landfill site (Tucuman, Argentina). Environ Geochem Health, 36(3), 489-503," Environmental Geochemistry and Health, vol. 36, no. 3, pp. 489-503, 2014.

[17] H. Xie, Y. Jiang, C. Zhang, S. Feng, and Z. Qiu, "Steady-state analytical models for performance assessment of landfill composite liners," Environmental Science and Pollution Research, vol. 22, no. 16, pp. 12198-12214, 2015.

[18] J. Havukainen, M. Zhan, J. Dong et al., "Environmental impact assessment of municipal solid waste management incorporating mechanical treatment of waste and incineration in Hangzhou, China," Journal of Cleaner Production, vol. 141, pp. 453-461, 2017.

[19] M. Vadiati, A. Asghari-Moghaddam, M. Nakhaei, J. Adamowski, and A. H. Akbarzadeh, "A fuzzy-logic based decision-making approach for identification of groundwater quality based on groundwater quality indices," Journal of Environmental Management, vol. 184, Part 2, pp. 255-270, 2016.
[20] V. P. Singh, C. P. Khedun, and A. K. Mishra, "Water, environment, energy, and population growth: implications for water sustainability under climate change," Journal of Hydrologic Engineering, vol. 19, no. 4, pp. 667-673, 2014.

[21] R. Nagarajan, S. Thirumalaisamy, and E. Lakshumanan, "Impact of leachate on groundwater pollution due to nonengineered municipal solid waste landfill sites of erode city, Tamil Nadu," Iranian Journal of Environmental Health Science \& Engineering, vol. 9, no. 1, pp. 1-12, 2012.

[22] M. M. Abd El-Salam and G. I. Abu-Zuid, "Impact of landfill leachate on the groundwater quality: a case study in Egypt. J. Adv. Res, 6(4), 579-586. Retrieved from," Journal of Advanced Research, vol. 6, no. 4, pp. 579-586, 2015.

[23] M. Zolfaghari, K. Jardak, P. Drogui, S. K. Brar, G. Buelna, and R. Dube, "Landfill leachate treatment by sequential membrane bioreactor and electro- oxidation processes," Journal of Environmental Management, vol. 184, Part 2, pp. 318-326, 2016.

[24] P. Kjeldsen, P. L. Bjerg, R. Kirstenm, T. H. Christensenm, and J. K. Pedersenm, "Characterization of an old municipal landfill (Grindsted, Denmark) as a groundwater pollution source: landfill hydrology and leachate migration," Waste Management \& Research, vol. 16, no. 1, pp. 14-22, 1998.

[25] M. P. Papadopoulou, G. P. Karatzas, and G. G. Bougioukou, "Numerical modelling of the environmental impact of landfill leachate leakage on groundwater quality - a field application," Environmental Modeling and Assessment, vol. 12, no. 1, pp. 43-54, 2007.

[26] A. T. Ahmed, A. E. Alluqmani, and M. Shafiquzzaman, "Impacts of landfill leachate on groundwater quality in desert climate regions," International journal of Environmental Science and Technology, vol. 16, no. 11, pp. 6753-6762, 2019.

[27] O. Aromolaran, O. E. Fagade, O. K. Aromolaran, E. T. Faleye, and H. Faerber, "Assessment of groundwater pollution near Aba-Eku municipal solid waste dumpsite," Environmental Monitoring and Assessment, vol. 191, no. 12, p. 718, 2019.

[28] J. S. Fandiño, A. Nagalli, and R. C. Moro Filho, "Modeling of the dispersion of pollutants in porous media: case of a landfill in Brazil," Journal of Environmental Chemical Engineering, vol. 8, no. 6, p. 104400, 2020.

[29] J. Zhang, J. M. Zhang, B. Xing, G. D. Liu, and Y. Liang, "Study on the effect of municipal solid landfills on groundwater by combining the models of variable leakage rate, leachate concentration, and contaminant solute transport," Journal of Environmental Management, vol. 292, article 112815, 2021.

[30] H. Bouwer and R. C. Rice, "A slug test for determining hydraulic conductivity of unconfined aquifers with completely or partially penetrating wells," Water Resources Research, vol. 12, no. 3, pp. 423-428, 1976.

[31] X. H. Chen, "Measurement of streambed hydraulic conductivity and its anisotropy," Environmental Geology, vol. 39, no. 12, pp. 1317-1324, 2000.

[32] Y. Huang, Z. F. Zhou, J. G. Wang, and Z. Dou, "Simulation of groundwater flow in fractured rocks using a coupled model based on the method of domain decomposition," Environment and Earth Science, vol. 72, no. 8, pp. 2765-2777, 2014.

[33] D. Schulze-Makuch, "Longitudinal dispersivity data and implications for scaling behavior," Groundwater, vol. 43, no. 3, pp. 443-456, 2005. 